\title{
Implementation Problem-Based Learning Model to Enhance Self-Regulated Learning on Material of Colloidal System
}

\author{
Ferdianti Fidya Aprillia, Utiya Azizah* \\ Chemistry Department \\ Universitas Negeri Surabaya \\ Surabaya, Indonesia \\ utiyaazizah@unesa.ac.id.
}

\begin{abstract}
This study aims to describe the learning process and the students' self-regulated learning through the implementation of the problem-based learning model. The obtained data were analyzed using quantitative descriptive approach. Results showed that: (1) The implementation of problem-based learning model to enhance students' selfregulated learning on colloidal system material was categorized well and very well during 3 meetings with the average percentage in phase 1 to phase 5 respectively $75 \%, 100 \%, 88 \%$, $79 \%$, and $100 \%$; (2) The students' self-regulated learning was successfully trained through the problem-based learning model and is in good category with the average percentage at each successive meeting are $74.89 \%, 77.90 \%$ and $78.80 \%$. This increase in students' self-regulated learning indicates that there is a significant difference which is proved by the nonparametric Friedman test with $p<0.05$. This shows that the problem-based learning model is able to enhance students' selfregulated learning on colloidal system material.
\end{abstract}

Keywords- Problem-based learning model, Self-regulated learning, Colloidal system

\section{INTRODUCTION}

The development of science in the $21^{\text {st }}$ century requires individuals to have very high abilities. Skills that must be possessed in the knowledge era 21 include: (a) Critical thinking skills and hard work, (b) Creativity, (c) Collaboration, (d) Understanding across cultures, (e) Communication, (f) Computing, (g) Career and independence [1]. In the 21 st century, students need to have metacognition competence and self-regulated learning as the key to improving their thinking skills [2]. Research findings state metacognitive skills that are applied in learning can train the pre-service teachers' self-regulated learning [3]. The importance of students' self-regulated learning has been supported by the existing education system in Indonesia, among others, the 2013 curriculum regulated in the Ministry of Education and Culture of Indonesian number 20 and 22 of 2017 and Strengthening Character Education (SCE) in the Republic of Indonesia Presidential Regulation number 87 of 2017.

Based on the results of the pre-research conducted on October 27, 2017, at Senior High School 1 Kebomas, Gresik Indonesia as much as $38.33 \%$ of students still did not goal setting before learning chemistry, $43.33 \%$ of students have not chemistry strategic planning, $60 \%$ self-efficacy of chemistry learning abilities is lacking, $53.33 \%$ do not have self-instruction, $45 \%$ of the attention focusing is still low, $60 \%$ do not have a strategy in carrying out tasks (task strategy), and $45 \%$ of students have not been able to selfevaluate their learning outcomes. Therefore, the quantity of students who have self-regulation learning is still low and needs to be improved again in order to achieve academic goals well.

Chemistry is one of the most important branches of science and allows students to understand what is happening around them. The chemistry curriculum generally combines many abstract concepts, which are important for further study in both chemistry and other sciences [4]. Chemical characteristics that are abstract and the material taught are very broad, making students feel difficulties in learning chemistry [5].

Based on the facts in school, as much as $76.67 \%$ of students said that the chemical material that was considered difficult was the colloidal system because the material was too much memorization and the teaching was not applied in everyday life. Students listen to the explanation of the teacher and conduct question and answer discussions so that students are required to be able to memorize the material given. Colloid material is considered as a difficult material which is also evidenced by the results of the initial ability of students which shows that students still have not understood the concepts in colloid through applicable colloidal questions in everyday life. Therefore, $56.67 \%$ of students expect to learn to use applicable practicum in everyday life on colloidal material because as much as $80 \%$ of students have never conducted an investigation and produced work related to problems in the colloidal system material.

Learning models that use practicum are applicable to daily life and aim to make students' self-regulated learning is a problem-based learning model. The syntax of problembased learning models includes five phases i.e. problems orientation, organization of learners, independent and group investigation, problem-solving development and presentation, and evaluation of the problem-solving process [6]. In problem-based learning models, students will play an active role during the learning process while the teacher's role is to present problems, ask questions, and facilitate inquiry and dialogue. Learners look for solutions to real problems that are formulated by themselves and learn to 
handle these solution search tasks independently [7]. Therefore, students' self-regulated learning can be trained through problem-based learning models based on existing phases. This is supported by the research state that the use of problem-based learning models can enhance students' selfregulated learning [8].

\section{METHODS}

The subjects of this study were students of class XI IPA 1 Senior High School 1 Kebomas, Gresik, Indonesia in the even semester of 2017/2018 school year. The research instrument used in this study is the observation sheet for the implementation of the problem-based learning model and inventory of students' self-regulated learning.

The results of this study were analyzed by descriptive quantitative. Analysis of observational data on the implementation of problem-based learning models by calculate the percentage of scores obtained in each phase. Analysis of students' self-regulated learning by calculate the percentage of self-regulated learning scores in each indicator, then averaging overall and statistical tests using SPSS 23 statistics to find out the differences in self-regulated learning at each meeting.

\section{RESULTS AND DISCUSSIONS}

Through the activities carried out, obtained data in the form of the implementation of problem-based learning models and students' self-regulated learning obtained the result as follows.

\section{A. Implementation of Problem-Based Learning Model}

Observation of the implementation of the learning model aims to observe the suitability of the teacher activities in applying problem-based learning models with the syntax that has been determined in lesson plan and shows that the teacher has trained students' self-regulated learning in the learning process for 3 meetings. The observation results of the implementation of problem-based learning models for 3 meetings are presented in Fig. 1.

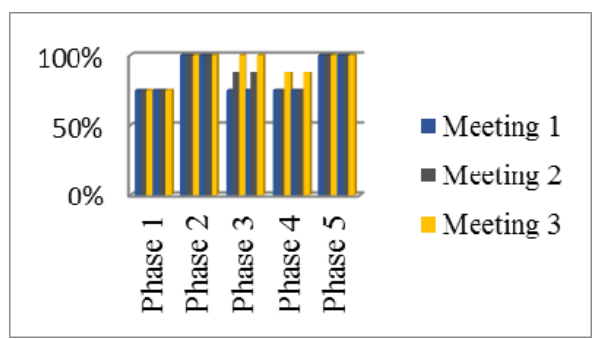

Fig. 1. Implementation of Problem-Based Learning Model

Based on Fig.1. shows that overall the teacher carries out each phase in the problem-based learning model in the good and very good category in each meeting with a percentage of $\geq 61 \%$. In phase 1 , orient students to actual and authentic problems get percentages at each meeting by $75 \%, 75 \%$, and $75 \%$. In this phase, the teacher presents a problem phenomenon which aims to bring real-world problems to the classroom to be investigated and analyzed. In this phase, the indicators of self-regulated learning that arise are selfrecording, attention focusing, and goal setting.
In phase 2, organizing students to learn to get a percentage at the third meeting of $100 \%$. In this phase, the teacher prepares students to conduct investigative activities including dividing students into several groups, distributing handouts, instructing students to make scientific questions, hypothesis, and problem-solving strategies. In this phase, the indicators of self-regulated learning that arise are goal setting and strategic planning. In phase 3, guiding individuals and groups in the investigation get percentages at each meeting by $75 \%, 87.5 \%$, and $100 \%$. In this phase, the teacher guides students during conducting investigations to test the hypotheses that have been made. In this phase the indicators of self-regulated learning that arise are self-experiments, selfinstructions, and task strategies.

In phase 4, helping students in developing and presenting the results of problem solving getting percentages at each meeting by $75 \%, 75 \%$, and $87.5 \%$. In this phase the teacher monitors the course of the discussion and guides students to present the results of the group discussion. Indicators of selfregulated learning that arise are self-efficacy, self-evaluation, attention focusing, and self-satisfaction. Phase 5, analyze and evaluate the problem solving process at all three meetings getting a percentage of $100 \%$. In this phase the teacher provides a review of things that overlap when the discussion process and evaluates the results of the student's investigation to clarify the correct concept. Indicators of selfregulated learning that arise are self-evaluation and goal setting.

\section{B. Students' Self-Regulated Learning}

Self-regulated learning is an active and constructive process in which students set goals for learning and try to monitor, regulate, and control cognition, motivation, and behavior by being guided and constrained by contextual goals and characteristics in the environment [9]. The students' self-regulated learning observation by questionnaire in the form of self-regulated learning inventory that has been developed and is feasible [10]. The following shows the value of students' self-regulated learning in each of the indicators during 3 meetings.

TABLE I. THE RESULT OF INVENTORY SELF-REGULATED LEARNING IN EACH MEETING

\begin{tabular}{|c|c|c|c|}
\hline Indicators & Meeting 1 & Meeting 1 & Meeting 1 \\
\hline Goal setting & $70,27 \%$ & $74,24 \%$ & $74,62 \%$ \\
\hline Strategic planning & $74,81 \%$ & $74,62 \%$ & $75,76 \%$ \\
\hline Self-efficacy & $67,93 \%$ & $72,22 \%$ & $74,49 \%$ \\
\hline Self-instruction & $77,27 \%$ & 80,68 & $80,30 \%$ \\
\hline Attention focusing & $80,11 \%$ & $84,09 \%$ & $85,61 \%$ \\
\hline task strategies & $82,01 \%$ & $83,71 \%$ & $85,61 \%$ \\
\hline Self-recording & $76,14 \%$ & $75,00 \%$ & $76,52 \%$ \\
\hline Self- experimentation & $73,48 \%$ & $81,06 \%$ & $79,55 \%$ \\
\hline Self-evaluation & $73,74 \%$ & $72,27 \%$ & $79,04 \%$ \\
\hline Self-satisfaction & $73,11 \%$ & $76,14 \%$ & $76,52 \%$ \\
\hline
\end{tabular}

Goal settings are trained in problem-based learning through defining goals, formulating problems, and formulating temporary assumptions based on phenomena. Based on Table 1, there is an increase in the percentage of students' self-regulated learning which shows students have been able to determine the purpose of the task to be carried out and are in a good category. Goal setting involves setting specific task objectives that can be used to direct cognition in general and particular monitoring [11]. Strategic planning is 
a process and action that aims to display skills. Properly chosen strategies will improve performance by aiding cognition, controlling, and directing motor execution [12]. Strategic planning is trained through activities of formulating variables and experimental designs in group discussion forums to solve problems and be in good categories.

Self-efficacy is a belief about what someone can do. Selfefficacy of students is seen when presenting the results of the investigation and expressing opinions (asking questions, answering questions, and giving responses). Table 1 shows that there is an increase in each meeting and is in a good category. Increasing self-efficacy can direct students to further strengthen the achievement of the goal settings they have made. Students' self-instruction of is in well and very well category which is trained through investigation and problem-solving activities in accordance with the experimental procedure and instructions given by the teacher and written reports of experimental results in accordance with the format given by the teacher. Self-instruction can help students in managing their personal processes such as attention, problem-solving, and motivation [13].

Attention focusing can be seen from students focusing on the problem in accordance with the concept of the material, paying attention to the teacher while presenting the material or giving instructions and paying attention to other students when presenting the results of their learning activities. Table 1 shows there is an increase in the students' self-regulated learning in maintaining concentration in doing assignments with the very well category. Task strategies of students are trained through the activities of working on questions in the worksheet related to the investigation process and completing the making of investigative work (written reports) in accordance with the concept of the material. Task Strategies students are in a very well category. Task Strategies can help learning and performance by processing tasks into the important parts and managing their parts meaningfully [12].

Self-observation is a process that guarantees information needed in directing the next self-regulated learning efforts and more meaningful when focused on certain conditions when the learning process takes place [14]. In problem-based learning activities, self-recording of students is trained through the activities of students using images to understand the phenomenon related to the material and using various learning resources (textbooks, handouts or the internet) to help the problem-solving process with a good category. Students' self-experimentation are trained through the activities of students to check the stage of investigation to solve problems that are in the good category. Selfexperimentation can help students to become aware of and monitor their own behavior and can provide information that can be used to control and regulate the behavior of students [12].

Self-evaluation of students is trained through the activities concluding the results of problem-solving according to the objectives, presenting the results of the investigation/problem solving in accordance with the objectives, working on evaluation questions as an application to solve problems, pay attention to presentation/exposure or assess the work of other groups and compare with the results of own group, and evaluate the problem-solving process. Table 1 shows that there is an increase in students' selfregulated learning in evaluating activities in good categories.
Self-evaluations are done repeatedly produce great benefits to goal achievement process and improving outcomes for all learners [15]. The self-satisfaction of students can be seen through students feeling satisfied with the results of the investigation that has been carried out and responding to responses, criticisms, and suggestions given by the teacher or other groups. Based on Table 1, it shows that there is an increase in students' self-regulated learning in having a sense of self-satisfaction with the results obtained and in a good category. Increased self-satisfaction can increase motivation while decreasing self-satisfaction can weaken further efforts to learn [16].

Based on the descriptions above, it shows that the students' self-regulated learning indicators in each meeting are in the good and very good category. This research is in line with the results of research applied in universities which show that pre-service teachers' have a high and very high level of self-regulated learning in each of these indicators [17]. Student' self-regulated learning with an average percentage at meetings I, II, and III respectively $74.89 \%$, $77.90 \%$, and $78.80 \%$ are in a good category because it has a percentage of $\geqslant 61 \%$. Increased student' self-regulated learning was tested using the SPSS Statistics 23 application through the Non-Parametric Friedman test. The hypothesis used to test different students' self-regulated learning is:

Ho $=$ there is no difference in students' self-regulated learning at the three meetings

$\mathrm{Ha}=$ there are differences in students' self-regulated learning at the three meetings

The following are the results of the Non-Parametric Friedman statistical test analysis in Fig. 2.

\begin{tabular}{|l|r|}
\begin{tabular}{|l|r|}
\hline Nest Statistics & \\
Chi-Square & 33 \\
df & 26.482 \\
Asymp. Sig. & 2 \\
\hline
\end{tabular} \\
a. Friedman Test
\end{tabular}

Fig. 2. Friedman Non-Parametrik Test Result

Fig. 2 shows that the value of $p=0.00$ so that because of the probability $<0.05$, Ho is rejected and Ha is accepted. This means that there are differences in students' self-regulated learning at the three meetings. To find out the differences that occurred in the three meetings, the non-parametric Wilcoxon test was conducted in the meeting group with all possible combinations. Wilcoxon non-parametric test results of students' self-regulated learning are presented in Fig. 3.

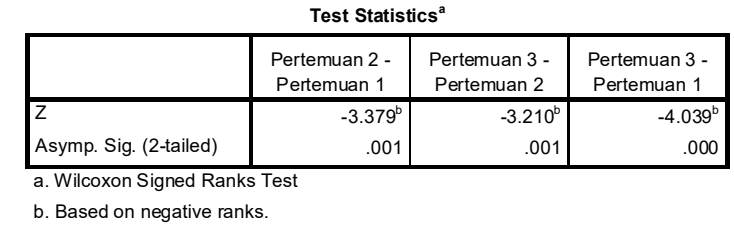

Fig. 3. Wilcoxon Non-Parametrik Test Result

Fig. 3 shows the results of the non-parametric test Wilcoxon Test has a value of $\mathrm{p}=0.001$ or less than 0.05 in the group of meetings 1 and 2, which means there are differences in students' self-regulated learning at meetings 1 and 2 . In meeting groups 2 and 3 have a value of $p=0.001$ 
or less than 0.05 , which means there are differences in students' self-regulated learning at meetings 2 and 3 . And in group meetings 1 and 3 have a value of $p=0,000$ or less than 0.05 , which means there are differences in students' selfregulated learning at meetings 1 and 3 . So it can be concluded that there are differences in students' selfregulated learning after being given a problem-based learning model.

\section{CONCLUSION}

Based on the description of the research results above, the conclusions that can be drawn are: (1) The implementation of problem-based learning models to enhance students' self-regulated learning on the colloidal system material was categorized well and very well during 3 meetings with the average percentage in Phase 1 to Phase 5 respectively $75 \%, 100 \%, 88 \%, 79 \%$, and $100 \%$ and (2) The student' self-regulated learning was successfully trained through the problem-based learning model and is in a good category with the average percentage at each successive meeting are $74.89 \%, 77.90 \%$, and $78.80 \%$. This increase in student' self-regulated learning indicates that there is a significant difference which is proved by the non-parametric Friedman test with $\mathrm{p}<0.05$.

\section{REFERENCES}

[1] B. Trilling, and P. Hood, "Learning Technology, and Education Reform in the Knowledge Age or "We're Wired, Webbed, and Windowed, Now What?” Educational Technology, 1999, pp. 5-18, Mei - June.

[2] O.S. Tan, "Cognition, Metacognition, and Problem Based Learning," in Enhancing Thinking through Problem Based Learning Approaches, O.S. Tan, Eds. Singapure: Thomson Learning, 2004, pp. 1 - 16.

[3] U. Azizah and H. Nasrudin, "Empowerment of metacognitive skills through development of instructional materials on the topic of hydrolysis and buffer solutions," Journal of Physics: Conference Series, 2018, https://doi:10.1088/1742-6596/953/1/012199.
[4] K.S. Taber, Alternative Conceptions in Chemistry: Prevention, Diagnosis and Cure? London: The Royal Society of Chemistry, 2002.

[5] E. Listari, "Pengaruh Model Pembelajaran Problem Based Learning Berorientasi Chemoenterpreneurship Terhadap Hasil Belajar Kimia SMA," Jurnal Ilmiah Pendidikan Kimia “Hidrogen,” 2013, vol 1, no 2, pp. 100-106.

[6] R. I. Arends, Belajar untuk Mengajar Buku 2 Edisi 9. Jakarta: Salemba Humanika, 2013.

[7] M. Nur, Model Pembelajaran Berdasarkan Masalah. Surabaya: Pusat Sains dan Matematika Sekolah Surabaya, 2011.

[8] S. Sungur, and C. Tekkaya, "Effect of Problem Based Learning and Traditional Instruction on Self Regulated Learning". The Journal of Educational Research., 2006, vol 99, no 5, pp. 307-320.

[9] D.H. Schunk, 2005. "Self Regulated Learning: The Educational Legacy of Paul R. Pintrich”. Educational Psychologist, 2005, vol. 40, no 2, pp 85-94

[10] U. Azizah, Suyono, and Suyatno, 2014. "Pengembangan Instrumen Untuk Mengukur Kemandirian Belajar Mahasiswa," Prosiding Seminar Nasional Kimia, 2014, pp. 155 - 159.

[11] P.R. Pintrich, "The role of goal orientation in self-regulated learning," in Handbook of Self-Regulation, M. Boekaerts, P. R. Pintrich, and M. Zeidner, Eds., San Diego, CA: Academic Press, 2000, pp. 451-502.

[12] M. Boekaerts, P.R. Pintrinch, M. Zeidner, Handbook of Self Regulation. San Diego, CA:: Academic Press, 2000.

[13] B.J. Zimmerman, "Self Regulated Learning and Academic Achievement: An Overview," Educational Psychologist, 1990, vol 25 , no 1 , pp. 3-17,

[14] A. Bramucci, Self Regulated Learning: Theories and Potential Application in Didactics, University of Macerata, 2013.

[15] D.H. Schunk, Teori-Teori Pembelajarab: Perspektif Pendidikan. Yogyakarta: Pustaka Belajar, 2012.

[16] B.J. Zimmerman, "Becoming A Self-Regulated Learner: An overview". Theory into Practice, 2002, vol 41, no 2, pp. 64 - 72.

[17] U. Azizah, Suyono, and Suyatno, "Profil Kemandirian Belajar Mahasiswa Calon Guru Sains pada Pembelajaran Materi Larutan (Hasil Uji Coba)," Prosiding Seminar Nasional Pendidikan Sains Program Pascasarjana Universitas Negeri Surabaya, 2015 